\title{
Protective Effects of Melatonin on Testicular Torsion and Detorsion Damage in Sprague-Dawley Rats
}

\author{
Efectos Protectores de la Melatonina en el Daño por Torsión \\ y Destorsión Testicular en Ratas Sprague-Dawley
}

"Ayfer Aktas; ** M. Cudi Tuncer; ***Ayse Yıldırım; "Yusuf Nergiz \& "Murat Akkus,

\begin{abstract}
AKTAS, A.; TUNCER, M. C.; YıLDıRıM, A.; NERGIZ, Y. \& AKKUS, M. Protective effects of melatonin on testicular torsion and detorsion damage in Sprague-Dawley rats. Int. J. Morphol., 29(1):7-15, 2011.

SUMMARY: In this study, we evaluated the ultrastructural findings of testis with systemic administration of different doses of melatonin during ischemic period in a rat model of testicular torsion/detorsion (T/D). Testis ischemia-reperfusion (I/R) injury was induced by torsion of the left testis, with a 720 degrees twisting of the spermatic cord so as to produce a total occlusion of testis for 2.5 hours. Subsequently, the same testis was then detorsioned. According to surgical procedure in each group, unilateral orchiectomies were performed for histopathologic examination. The groups were labelled as control group, torsion group (T), torsion and detorsion group ( $\mathrm{T} /$ D), torsion-detorsion and melatonin group (T/D+20,50 and $100 \mathrm{mg} / \mathrm{kg}$ melatonin). For the histological examination, testicular tissues were fixed in $2.5 \%$ glutheraldehyde and postfixation $1 \%$ osmic acid solutions. They were examined under transmission electron microscopy after application of contrast stained. In torsion group testis cross-sections, cytoplasm residues of mature sperms and large vacuole-like structures were noticeable. In detorsion group testis cross-sections, dissociations in spermatocide nuclei, many vacuoles and residual particles resulting from organelle degeneration, local voids in cytoplasms of spermatogonia, dilatation in granulated endoplasmic reticulum, large lipid droplets, chromatid particles, along with mitochondrial crystalisis were determined. In the testis cross-sections of the group of $\mathrm{T} / \mathrm{D}+50 \mathrm{mg} / \mathrm{kg}$ melatonin administration, sertoli and spermatogonia cells that showed membrane-like structures and cytoplasmic voids were observed. Testis cross-sections of rats that were administered with T/D+50 mg/kg melatonin showed small mitochondrions and vacuole-like structures placed on the edge. Testis cross-sections of rats that were administered with T/D+100 mg/kg melatonin resulted in views similar to those of controls in the microstructural level. As a result, the most effective dose of melatonin, which was used in different doses, for prevention of ischemia/reperfusion damage was found to be $100 \mathrm{mg} / \mathrm{kg}$.
\end{abstract}

KEY WORDS: Testis; Torsion; Detorsion; Spraque-Dawley rat; Melatonin.

\section{INTRODUCTION}

Treatment of testicular torsion is the immediate operative exploration of the scrotum. The severity of testicular damage is related to the time and degree of torsion (Heindel et al., 1990). An aggressive surgical approach has improved testicular salvage rates (Anderson \& Williams, 1990). Testicular torsion was first described by Hunter. It is a medical and a urological emergency as it can lead to permanent ischaemic injury of the involved testis (Nussbaum Blask et al., 2002; McAndrew et al., 2002). Aetiologically, based on anatomy and age, testicular torsion is divided into two types. These are intravaginal and extravaginal types. Intravaginal is the more common type of testicular torsion.
The most common anatomic anomaly identified in this type of testicular torsion is a narrow attachment of the tunica vaginalis from the spermatic cord to the testes secondary to high insertion of the tunica on the spermatic cord. This results in the bell clapper anomaly characterised by increased testicular mobility. In nearly $80 \%$ of patients this anomaly is bilateral. Intravaginal testicular torsion is commonly seen in adolescents and older males. This type of torsion commonly occurs during sleep. Extravaginal type of testicular torsion is usually seen in the prenatal or neonatal period. Prenatal torsion usually occurs in utero around 32 weeks. Its exact cause is unknown and usually no anatomic

\footnotetext{
Department of Histology and Embryology, Faculty of Medicine, Dicle University, Diyarbakir, Turkey.

** Department of Anatomy, Faculty of Medicine, Dicle University, Diyarbakır, Turkey.

**** Department of Histology and Embryology, Faculty of Medicine, Mustafa Kemal University, Hatay, Turkey.
} 
defect that can explain the torsion can be identified. It is usually present at birth and carries a poor prognosis in terms of testicular salvage rates. It is commonly seen in neonates and is often mistaken for a scrotal haematoma.

Pathologically, testicular torsion results in rotation of the testicular vascular pedicle resulting in testicular ischaemia and ultimately infarction if it is not urgently addressed. Uisser and Heyns have shown that the extent of the ischaemia and infarction depends on the duration and the degree of the torsion (Visser \& Heyns, 2003). The median degree of torsion in patients who undergo surgical exploration but do not require orchidectomy is less $\left(360^{\circ}\right)$ compared with those who undergo surgical exploration and require orchidectomy $\left(540^{\circ}\right)$ (Arena et al., 2006). Depending on the duration, the gross pathological changes may vary from congestion in the early stages to haemorrhagic infarction in the later stages.

Testicular torsion is the most common genital trauma of the adolescent boy and has been implicated in testicular injury, altered hormone production, subfertility and infertility (Prillaman \& Turner, 1997) Although the basic pathological mechanism underlying testicular injury has not been completely understood, it has been shown that reactive oxygen species (ROS), formed during ischemiareperfusion, play an important role in this process (Prillaman \& Turner; Blank et al., 1993). Ischemia with consecutive reperfusion causes oxidative stress, which is characterized by an imbalance between ROS and the antioxidative defense system (Prillaman \& Turner; Kehinde et al., 2005). It is a pathologic condition that renders the testis ischemic, and surgical intervention is usually required to reestablish blood flow (Williamson, 1985). Even with successful surgical repair, loss of spermatogenesis and a significant increase in germ cell apoptosis may occur due to an increase in testicular oxidative stress concomitant with reperfusion (Lysiak et al., 2002).

Previous studies using a rat model of testicular torsion have demonstrated that a 1 -hour, $720^{\circ}$ rotation of the testis followed by reperfusion results in the permanent loss of spermatogenesis (Sun et al., 2006). For these reasons, different therapeutic strategies have been investigated with the aim of reducing short- and longterm testis reperfusion damage. In agreement with the ischemiareperfusion injury hypothesis and the role of free radicals in the disease process, numerous experimental animal studies have confirmed the efficacy of antioxidants in reducing the short-term damaging effect of torsion of the testis (Blank et al.; Romeo et al., 2004; Power et al., 2003) Theoretically, antioxidants have a dual effect on testicular injury due to ischemia-reperfusion: they limit the development of damage by decreasing free radicals generated by lipid peroxidation and counteract ROSmediated activation of inflammatory reaction (Romeo et al.; Reilly et al., 1991; Oner-Iyidogan et al., 2001).

Melatonin, which is secreted by the pineal gland, has been shown recently to be a potent free radical scavenger (Pieri et al., 1994). It has both a lipophilic and hydrophilic compound (Shida et al., 1994). Thus, it freely permeates all morphophysiological barriers of cells in any organ (Reiter, 1996). This study was instituted to evaluate the benefits of antioxidant effects of different melatonin doses in I/R injury after experimental testicular torsion and detorsion.

\section{MATERIAL AND METHOD}

Animals. All procedures complied with the standards for care and use of animal subjects as stated in the Guide for the Care and Use of Laboratory Animals (Institute of Laboratory Animal Resources, Dicle University). Sprague-Dawley male rats (250-300 g) fed on a standard diet and with tap water $\mathrm{ad}$ libitum, in a $12 \mathrm{~h}$ light-dark cycle were used.

Experimental design. Sprague-Dawley male rats were divided into 6 groups, each containing 7 rats. All animals were anesthetized with an intraperitoneal injection of $50 \mathrm{mg} / \mathrm{kg}$ of sodium pentobarbital. Control animals ( 0 hours of torsion) had left testis exposed for 15 minutes, then similarly replaced into the scrotum with orchiopexy. In torsion group (T), ischemia injury was induced by torsion of the left testis, with a 720 degrees twisting of the spermatic cord so as to produce a total occlusion of testis for 2.5 hours. In torsion and detorsion group (T/D), same protocol as in torsion group was performed to all rats. Subsequently, the left testis was re-placed into the scrotum and fixed in place both medially and laterally using 6-0 silk suture, and the scrotum was closed with wound clips. At the end of the appropriate interval, all animals underwent detorsion of the left testis. In torsion-detorsion and melatonin group (T/D+20 mg/kg melatonin), same protocol as in torsion and detersion group was performed in all rats. Afterwards, $20 \mathrm{mg} / \mathrm{kg}$ melatonin was injected intraperitoneally. In torsiondetorsion and melatonin group (T/D+50 mg/kg melatonin), same protocol as in torsion and detersion group was performed in all rats. Afterwards, $50 \mathrm{mg} / \mathrm{kg}$ melatonin was injected intraperitoneally. In torsion-detorsion and melatonin group (T/D+100 mg/kg melatonin), same protocol as in torsion and detersion group was performed in all rats. Afterwards, 100 $\mathrm{mg} / \mathrm{kg}$ melatonin was injected intraperitoneally. In all groups, all left testes removed and processed for histopathologic examination (short-term). 
Processing of histologic samples. The testis was removed from each group, for electron microscopic examination, the pieces of testicular tissues were fixed in $2,5 \%$ gluteraldehyde in $0,1 \mathrm{M}$ sodium phosphate buffer. Following this the tissue was fixed for $2 \mathrm{~h}$ in the same fixative sollution at $4^{\circ} \mathrm{C}$. The tissue was then thoroughly washed three times in a $0,1 \mathrm{M}$ sodium phosphate buffer and postfixed in $1 \%$ osmium tetroxide in a $0,1 \mathrm{M}$ sodium phosphate buffer at $4^{\circ} \mathrm{C}$. After repeated washings, the tissue was dehydrated in a graded series of alcohol and embeded in araldite CY212. The blocks were cut on microtome (LKB-8800 ultratome). Semi-thin sections, $1 \mu \mathrm{m}$ thick, were routinely stained with toluidin blue for light microscopy. Ultrathin sections, 60-80 nm thick, were contrasted with uranyl acetate and lead citrate, and examined with a transmission electron microscope (JEOL 1010) operating at $80 \mathrm{kV}$.

\section{RESULTS}

Histopathologic results. In control group, normal histologic structures were observed in ultrastructural level in rat testis cross-sections (Fig.1). Torsion group testis cross-sections showed local voids in spermatogonia cell membranes and cytoplasmic particles among cells (Fig. 2a). In another testis cross-section of the same group, cytoplasm residues and large vacuole-like structures were noticeable (Fig. 2b). Detorsion group testis cross-sections showed dissociations in spermatocide nuclei, many vacuoles and residual particles resulting from organelle degeneration (Fig. 3a). In some cross-sections, local voids in spermatogonia cytoplasms and dilatation in granulated endoplasmic reticulum were observed (Fig. 3b). In another cross-section of the same

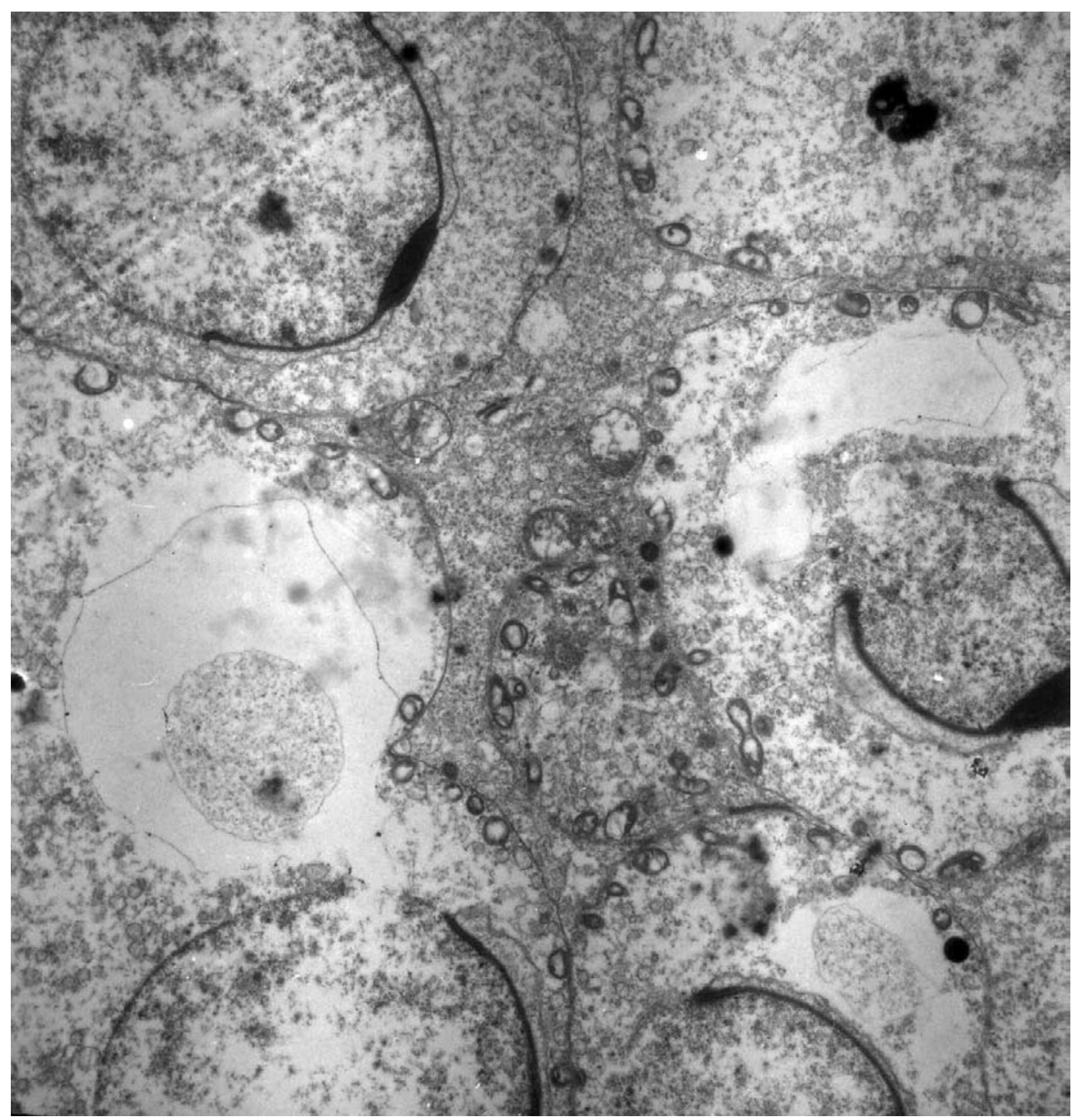

Fig 1. Normal testicular appearance in control group (Uranyl nitrate-Lead acetate x 3000). 


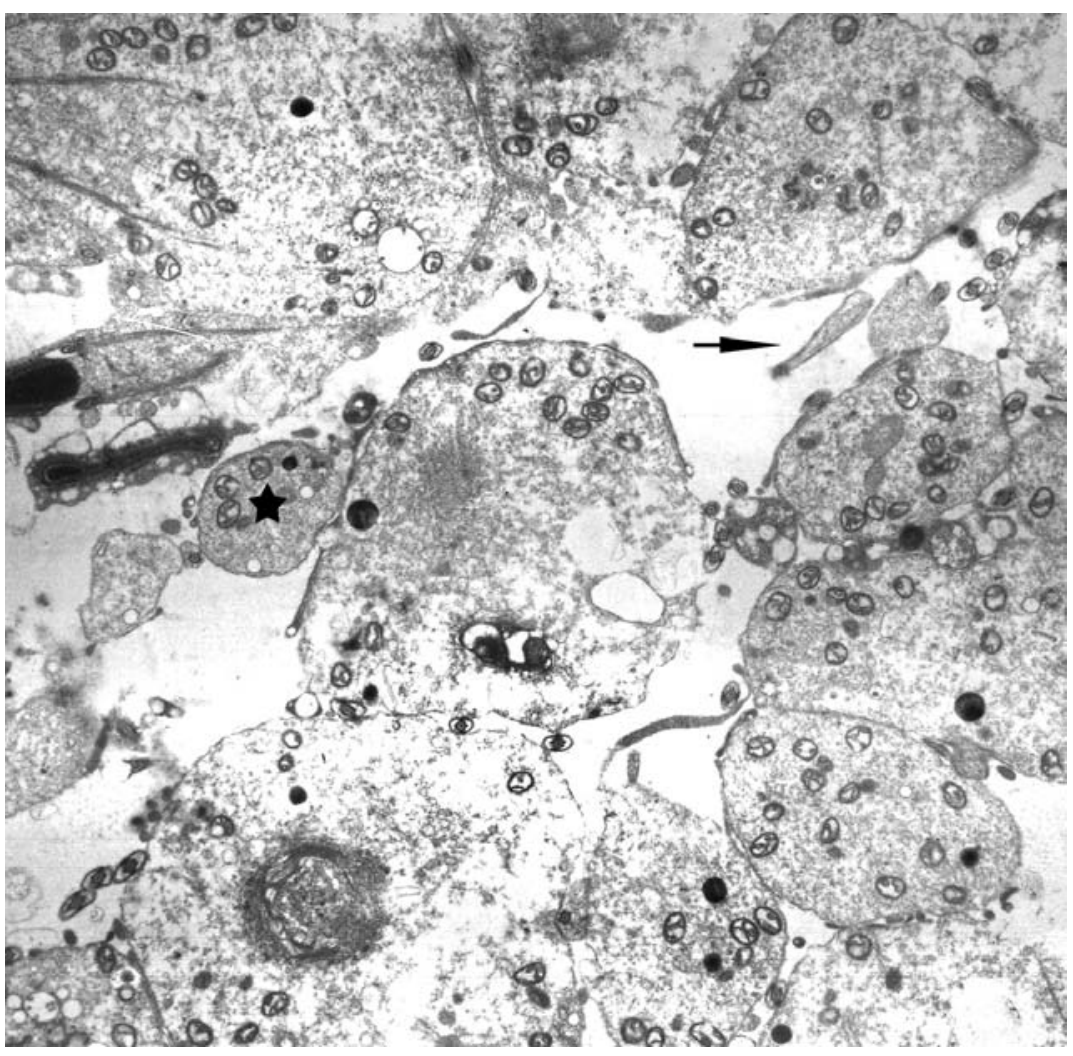

Fig. 2a. Voids in spermatogonia cell membrane and particles belonging to sperm and cytoplasm are observed in torsion group (Arrow: sperm particles, *: cytoplasmic particles), (Uranyl nitrate-Lead acetate x 3000).

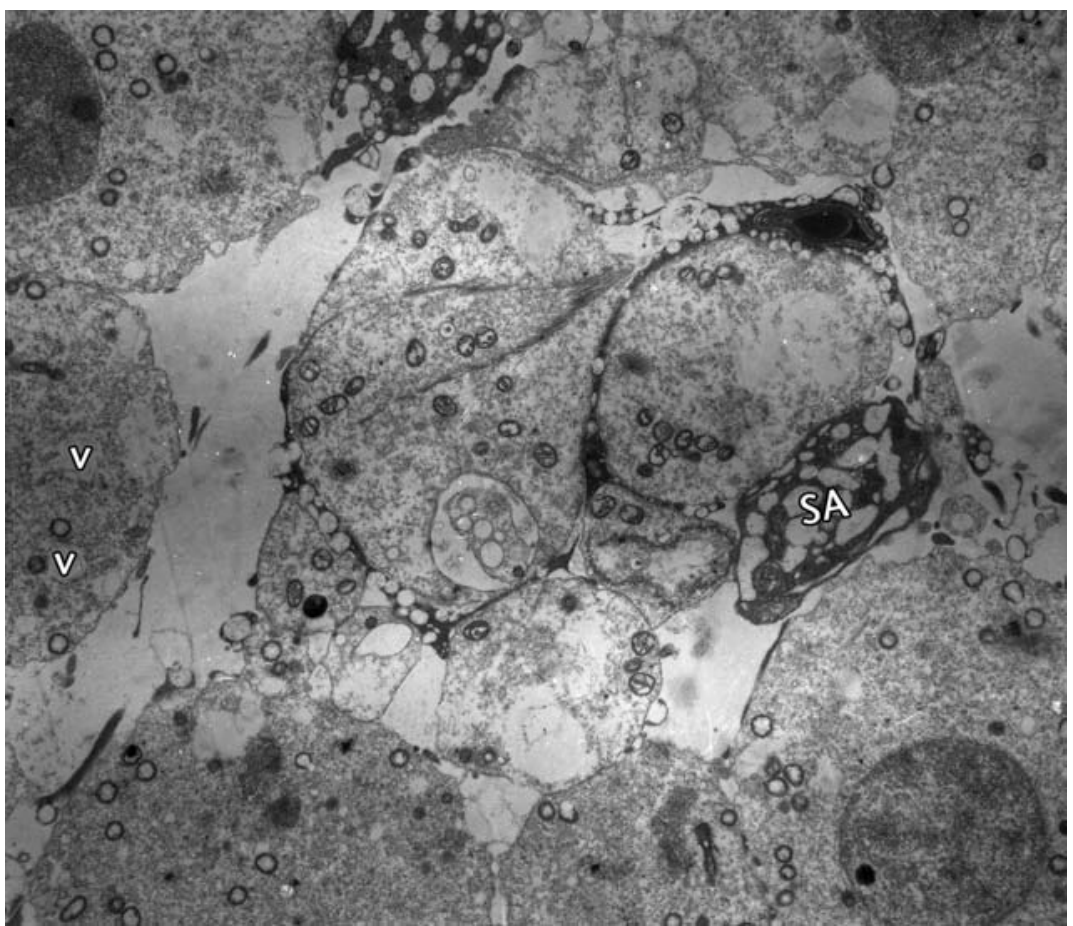

Fig. 2b. Cytoplasmic residues of mature sperm and large vacuole-like structures among cells are noticeable in torsion group (SA: Cytoplasmic residues, V: Vacuole), (Uranyl nitrate-Lead acetate x 3000). group, large lipid droplets, chromatid particles, along with mitochondrial crystalisis were determined (Fig. 3c). In the testis cross-sections of the group of $\mathrm{T} /$ $\mathrm{D}+20 \mathrm{mg} / \mathrm{kg}$ melatonin administration, sertoli and spermatogonia cells showing membrane-like structures and cytoplasmic voids were observed (Fig. 4). Testis crosssections of rats administrated with T/D+50 $\mathrm{mg} / \mathrm{kg}$ melatonin showed small mitochondrions and vacuole-like structures placed on the edge (Fig. 5). Testis cross-sections of rats administered with T/D+100 mg/kg melatonin showed views similar to those of controls in the microstructural level (Fig. 6).

\section{DISCUSSION}

Testicular torsion results in infertility and testicular damage. It has been shown that 1 hour of minimum time causes testicular damage after experimental testicular torsion in the rat (Turner \& Brown, 1993). Thus, we formed 2.5-hour testicular torsion model rotating left testis $720^{\circ}$ to constitute a severe testicular damage. The importance of these observations lies in their relation to infertility problems associated with spermatic cord torsion. Initially, torsion of the spermatic cord occludes the veins but not the arteries, resulting in edema, hemorrhagic infarction, and generalized ischemia of the testis (Skoglund et al., 1970). Due to this reason, we prefered testicular torsion methodology instead of arterial clamping to constitute ischemic damages in the testis.

Testicular torsion is a medical emergency occurring primarily in adolescent males and young men. Surgical detorsion should be performed on the ipsilateral testis. Even with succeful surgical repair, however, testicular atrophy is a common clinical outcome and is a significant urological issue (Turner $e t$ al., 2004). Testicular torsion needs to be distinguished from other acute causes of acute scrotal pain such as strangulated her- 


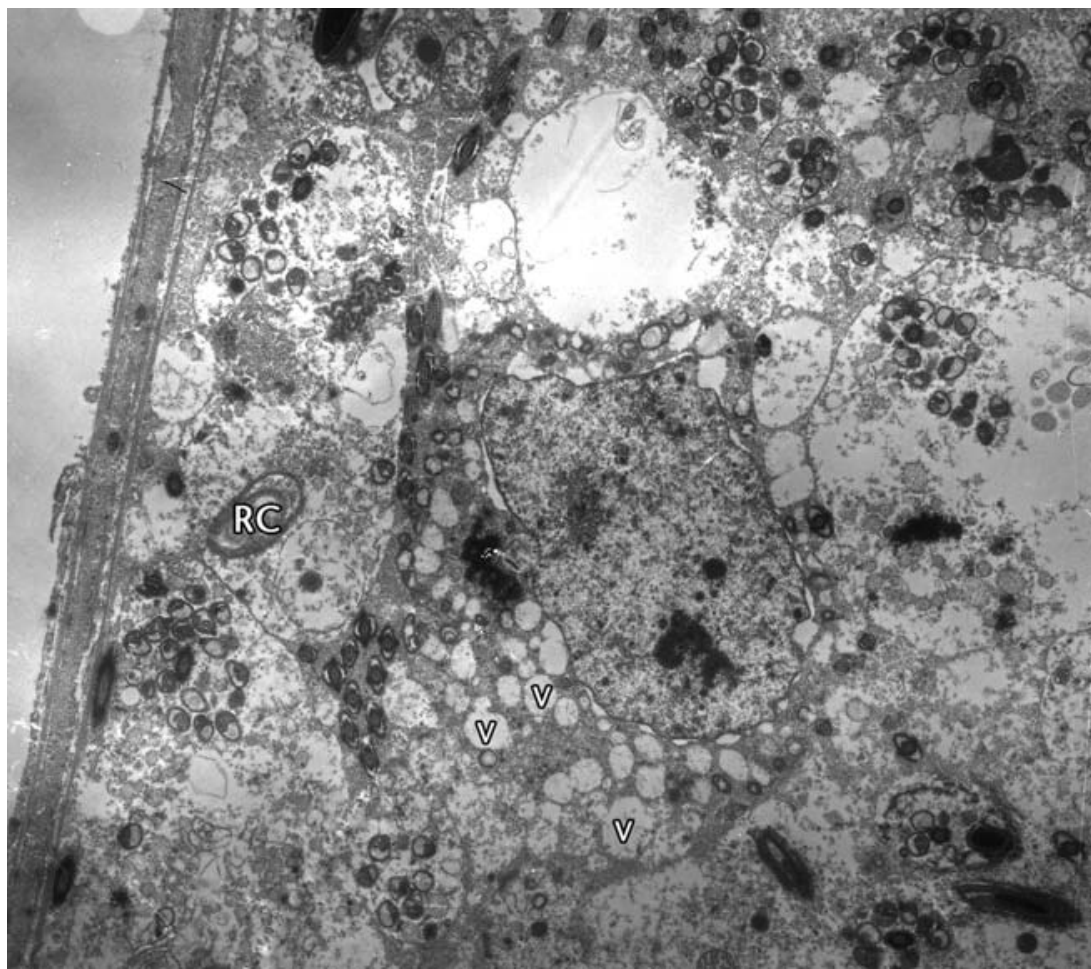

Fig. 3a. Dissociations in spermatocide nuclei and many vacuoles and residual particles resulting from organelle degeneration are observed in detorsion group (Rc: Residual particle, v: vacuole), (Uranyl nitrate-Lead acetate x 3000).

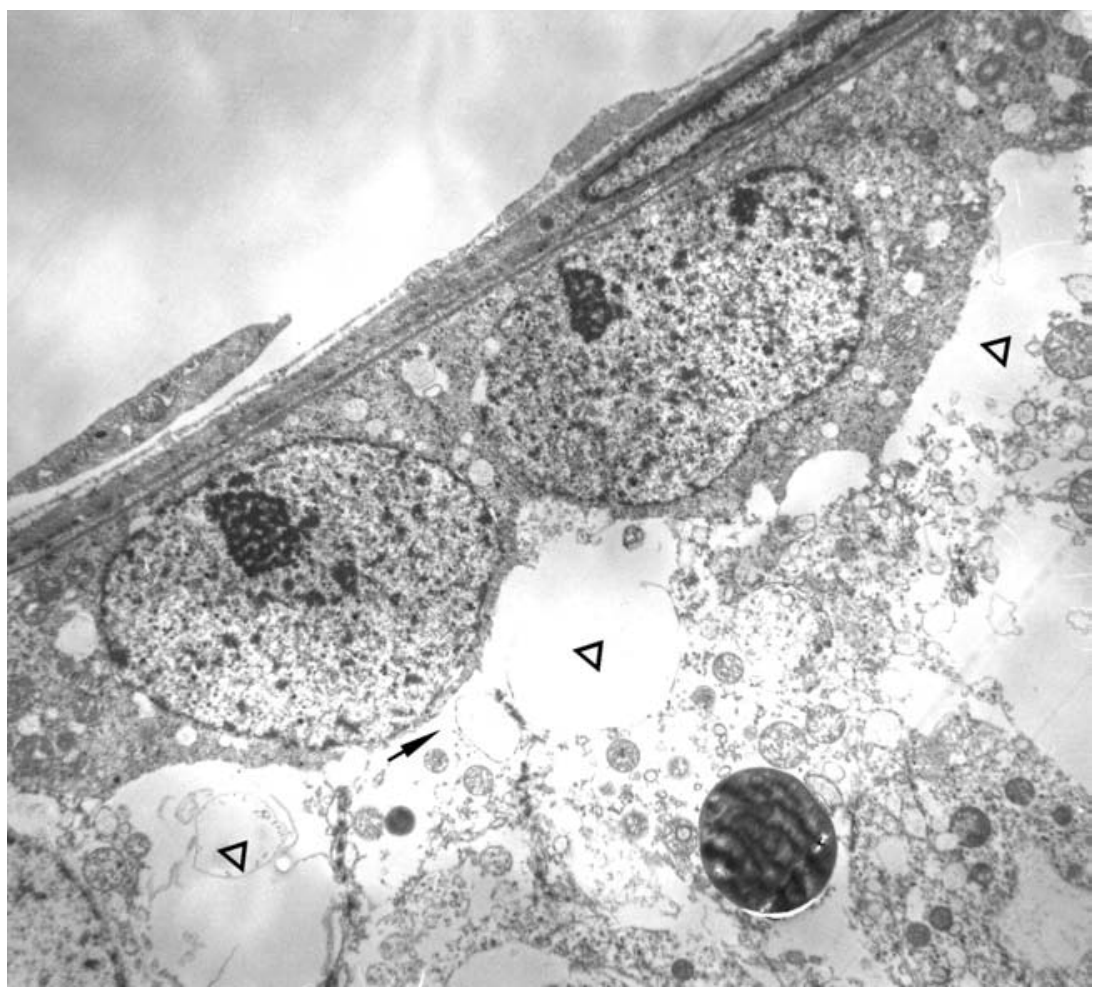

Fig. 3b. Voids in cytoplasm of spermatogonia and dilatation of granular endoplasmic reticulum (GER) in detorsion group ( $\Delta$ : cytoplasmic void, double arrow: dilated GER), (Uranyl nitrate-Lead acetate x 3000). nias, orchitis, epididymitis and torsions of the testicular appendages. In testicular torsion, the pain is more severe and acute at onset compared with epididymoorchitis. Torsion of a testicular appendage accounts for $35-67 \%$ of all cases of acute scrotal pain in children (Strauss et al., 1997).

During ischemia, ATP production decreases because of the limited oxygen availability. Intracellular $\mathrm{Ca}+2$ concentration rises depending on the influx of $\mathrm{Ca}+2$, leading to proteolytic conversion of xanthine dehydrogenase to $\mathrm{XO}$, which is a superoxide generator enzyme. During reperfusion, oxygen becomes abundant, and superoxide anions are generated by $\mathrm{XO}$ and the mitochondrial electron transport chain. In addition, ischemia activates the complement system and forms chemotactic factors, leading to a migration of polymorphonuclear leukocytes, which generate superoxide radicals, to the ischemic region after reperfusion (Dokmeci et al., 2007). This situation promotes lipid peroxidation and testicular tissue damage. Until now, a number of chemicals and drugs have been succesfully used to reduce the I/R injury in animal models of testicular torsion, but few of them are currently in clinical use (Turner et al.; Behestian et $a l ., 2008)$. For this reason, we aimed to explain how the different doses of melatonin beneficial effects against I/R injury in the rat testis. In recent years, several antioxidant agents have been used to prevent I/R-induced tissue damage in experimental testicular torsion such as catalase, allopurinol superoxide dismutase (Behestian et al.). There are several strategies to decrease the effect of oxygen free radicals after I/ R. Melatonin, which is a potent antioxidant agent, not only is a direct scavenger of toxic hydroxyl radical, but it also stimulates the activity of the antioxidative enzyme glutathione peroxidase (Pablos et al., 1995). Greenstein et al. (1992) and Blank et al. used antioxidant agents to prevent 


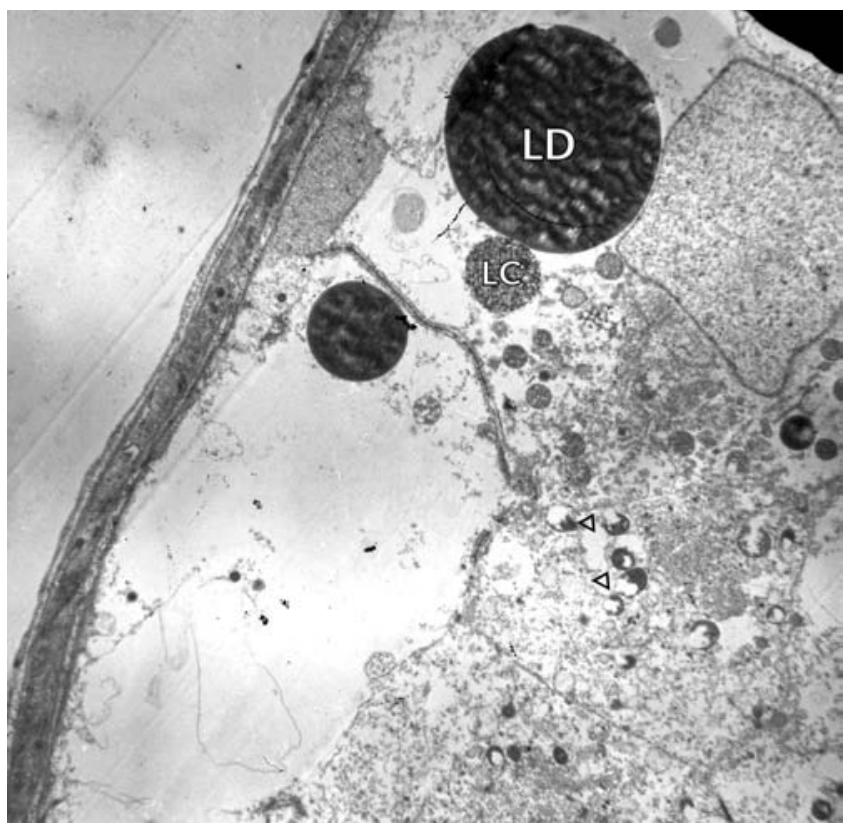

Fig. 3c. Large lipid droplets and chromatid particles, along with mitochondrial crystalisis is noticeable in detorsion group (LD: Lipid droplets, KC: Crystaloid particle, ?: Mitochondrial crystalisis), (Uranyl nitrate-Lead acetate x 3000).

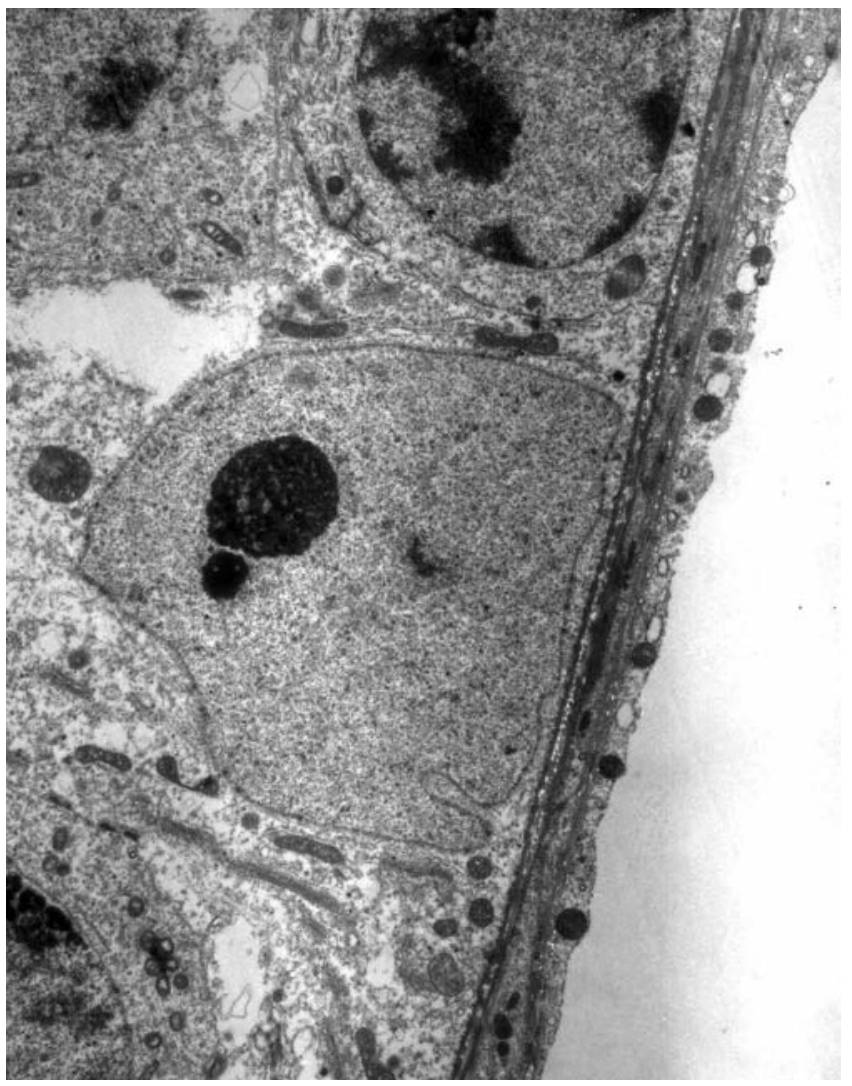

Fig. 4. Sertoli and spermatogonia cells with normal structure except for membrane-like structures and cytoplasmic voids are viewed in $\mathrm{T} / \mathrm{D}+20 \mathrm{mg} / \mathrm{kg}$ melatonin group (Uranyl nitrate-Lead acetate x 3000). testicular damage after 3 hours and 6 hours of torsion, respectively. However, we determined that melatonin treatment prevents $\mathrm{I} / \mathrm{R}$ injury in testicular tissue histopathologically after 2.5 hours of torsion in our study.

Recent investigations on oxidative stress and reactive oxygen species generation after testicular torsion suggest that pre-treatment with antioxidants can protect the testis against reactive oxygen species insult (Power et al.). Melatonin is known to be a free radical scavenger and inhibits the peroxidation of membrane lipids (Wakatsuki et al., 1999). Its lipophilicity ensures that melatonin rapidly enters cells and may accumulate in the nucleus. Thus, melatonin protects DNA against oxidative damage (Cabrer et al., 2001; Wakatsuki et al.). Kotler et al. (1998) have shown that melatonin increases the mRNA levels for glutathione peroxidase and superoxide dismutase in the rat brain cortex. In addition, melatonin modulates the androgen milieu and controls the immune response (Valenti \& Giusti, 2002). Gorman \& Yellon (1996) have shown that melatonin stimulates testis development as well. The protective effect of melatonin on lipid peroxidation has previously been shown in many investigations related to I/R injury in other tissues and this protective effect was reported to arise from its action as a direct free radical scavenger (Rodriguez et al., 2004). Because of its well-known antioxidant characteristics, we investigated its effects on the present experimental model.

In conclusion, we determined that testicular tissue injury was decreased after melatonin administration. To prevent I/R injury, it was found that the most effective dose of different doses of melatonin administrated was $100 \mathrm{mg} /$ $\mathrm{kg}$. And, we observed that melatonin treatment prevents I/ $\mathrm{R}$ injury histopathologically when examined in our histopathologic results.

AKTAS, A.; TUNCER, M. C.; YILDıRıM, A.; NERGIZ, Y. \& AKKUS, M. Efectos protectores de la melatonina en el daño por torsión y destorsión testicular en ratas Sprague-Dawley. Int. J. Morphol., 29(1):7-15, 2011.

RESUMEN: Se evaluaron, en un modelo de torsión/detorsión (T/D) testicular en rata, los cambios ultraestructurales producidos en los testículos, posterior a la administración sistémica de diferentes dosis de melatonina, durante el período de isquemia. La lesión de isquemia-reperfusión (I/R) testicular fue inducida por la torsión del testículo izquierdo, con un giro de 720 grados del cordón espermático con el fin de producir una oclusión total de los testículos durante 2,5 horas. Posteriormente, los mismos testículos fueron detorsionados. De acuerdo con el procedimiento quirúrgico en cada grupo, fueron realizados exámenes histopatológicos de las orquiectomías unilaterales. Los gru- 


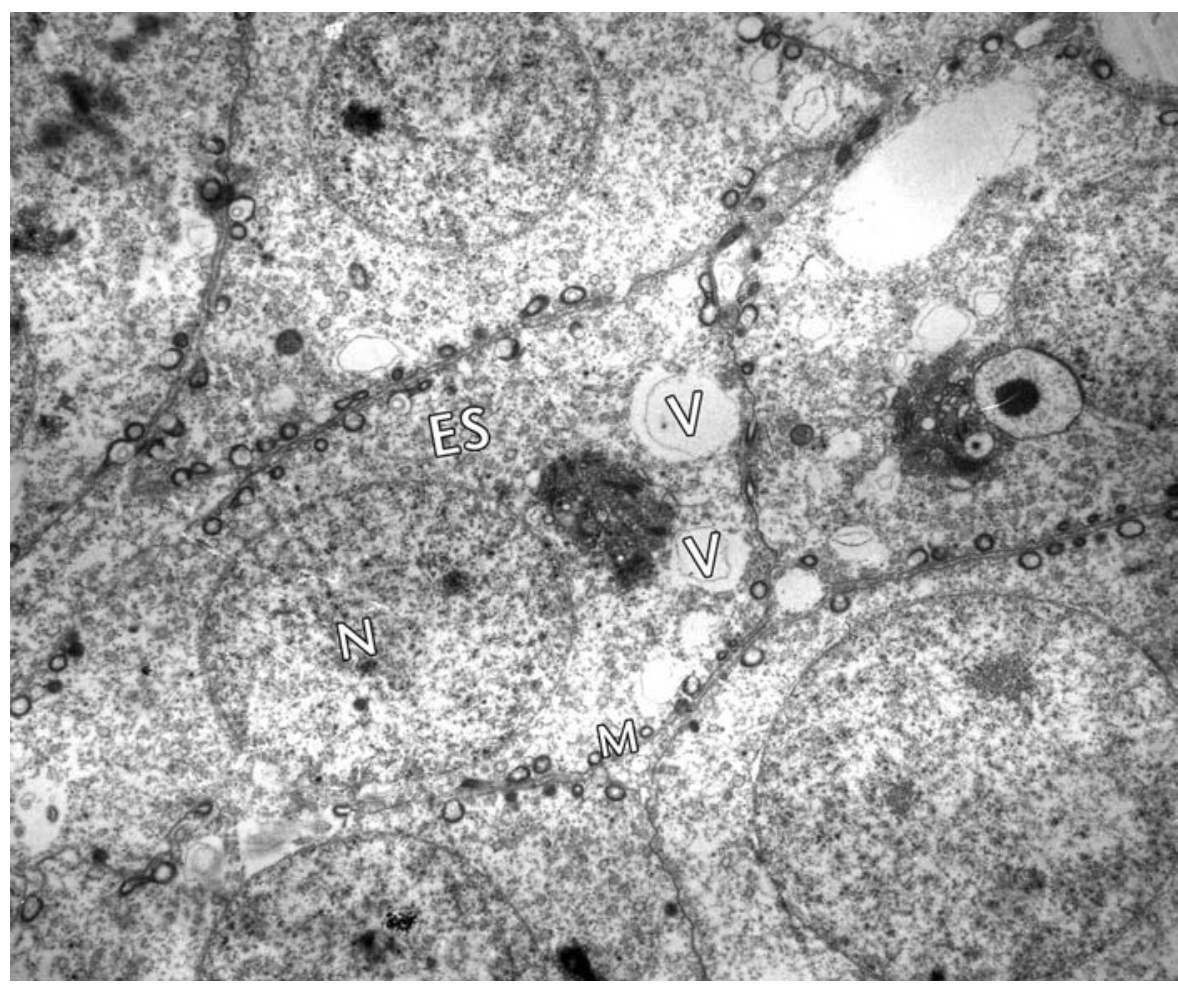

Fig. 5. Early spermatocide view characterized by small mitochondrions and vacuole-like structures are placed on the edge in T/D+50 mg/kg melatonin group (M: Mitochondrion, $\mathrm{N}$ : Nucleus, ES: Early spermatid, V: Vacuole), (Uranyl nitrate-Lead acetate x 3000).

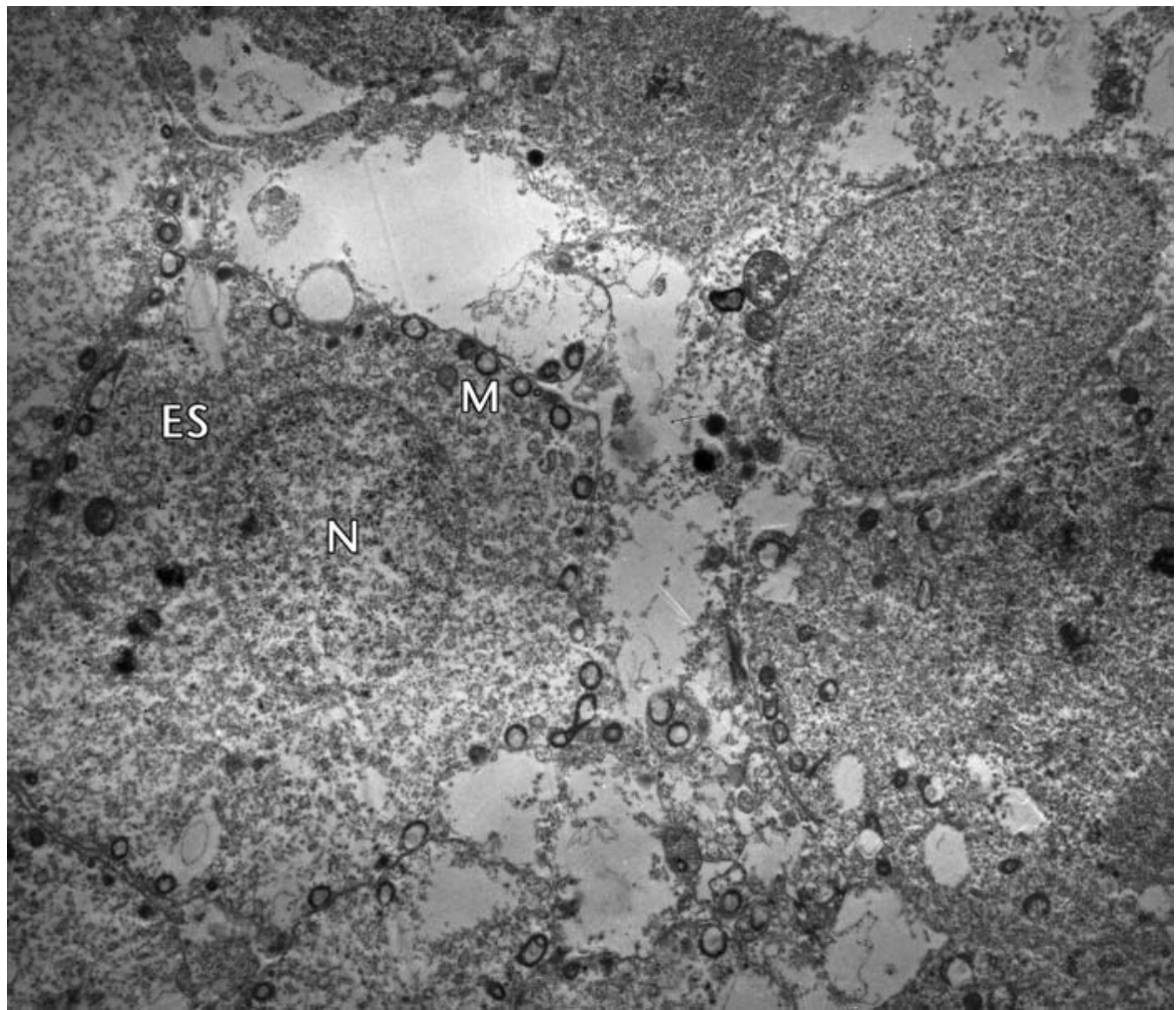

Fig. 6. The similary appearance of control group in T/D+100 $\mathrm{mg} / \mathrm{kg}$ melatonin group. (M: Mitochondrion, N: Nucleus, ES: Early spermatid), (Uranyl nitrate-Lead acetate x 3000). pos fueron divididos en grupo control, grupo torsión (T), grupo torsión/ destorsión (T/D), y grupo torción/ destorsión con melatonina (T/D +20, 50 y $100 \mathrm{mg} / \mathrm{kg}$ de la melatonina). Para el examen histológico, los tejidos testiculares fueron fijados en soluciones de glutaraldehído al 2,5\% y postfijados al $1 \%$ en ácido ósmico. Luego fueron examinados, después de la aplicación de contrastes de colores, a través de microscopía electrónica de transmisión. En las secciones transversales del grupo con torsión testicular, fueron visibles residuos citoplasmáticos de espermatozoides maduros y grandes estructuras vacuolares. En las secciones transversales del grupo con destorsión testicular, se observaron disociaciones en los núcleos espermáticos, numerosas vacuolas y partículas residuales derivadas de la degeneración de organelos; además de espacios localizados en el citoplasma de las espermatogonias, dilatación en el retículo endoplasmático rugoso, grandes gotas de lípidos y partículas de cromátidas, junto con cristálisis mitocondrial. En las secciones transversales del grupo T/D +50 mg/kg de administración de melatonina, células sustentaculares y espermatogonias mostraron estructuras tipo membrana y vacíos citoplasmáticos. Las secciones transversales del grupo con torsión en las que fue administrado $50 \mathrm{mg} / \mathrm{kg}$ de melatonina mostraron mitocondrias pequeñas y estructuras como vacuolas ubicadas en el borde. Las secciones transversales testiculares de las ratas en las que fue administrado $100 \mathrm{mg} /$ $\mathrm{kg}$ de melatonina, se observaron características similares a los controles a nivel microestructural. Como resultado, la dosis más eficaz de melatonina utilizada para la prevención del daño por isquemia-reperfusión (I/R) fue de $100 \mathrm{mg} / \mathrm{kg}$.

PALABRAS CLAVE: Testículos; Torsión; Destorsión; Rata Spraque-Dawley; Melatonina. 


\section{REFERENCES}

Anderson, J. B. \& Williams, R. C. Fertility after torsion of spermatic cord. Br. J. Urol., 65:225-30, 1990.

Arena, F.; Nicòtina, P. A.; Romeo, C.; Zimbaro, G.; Arena, S.; Zuccarello, B.; et al. Prenatal testicular torsion: ultrasonographic features, management and histopathological findings. Int. J. Urol., 13:135-41, 2006.

Beheshtian, A.; Salmasi, A. H.; Payabvash, S.; Kiumehr, S.; Nezami, B. G.; Rahimpour, S.; et al. Role of endogenous cannabinoids in ischemia/reperfusion injury following testicular torsion in rats. Int. J. Urol., 15:449-54, 2008.

Blank, M. L.; O'Neill, P. J.; Steigman, C. K., Cobb, L. M.; Wilde, R. A.; Havenstein, P. J.; et al. Reperfusion injury following testicular torsion and detorsion in prepubertal rats. Urol. Res., 21:389-93, 1993.

Cabrer, J.; Burkhardt, S.; Tan, D. X.; Manchester, L. C.; Karbownik, M. \& Reiter, R. J. Autoxidation and toxicant induced oxidation of lipid and DNA in monkey liver: Reduction of molecular damage by melatonin. Pharmacol. Toxicol., 89:225-30, 2001.

Dokmeci, D.; Inan, M.; Basaran, U. N.; Yalcin, O.; Aydogdu, N.; et al. Protective effect of L-carnitine on testicular ischaemia reperfusion injury in rats. Cell. Biochem. Funct., 25:611-8, 2007.

Gorman, M. R. \& Yellon, S. M. Three daily melatonin infusions alter gonadal development but not $\mathrm{GnRH}$ neuron number in the medial preoptic area or diagonal band of Broca in Siberian hamsters. Neurosci. Lett., 210:165-8, 1996.

Greenstein, A.; Smith-Harrison, L. I.; Wakely, P. E.; Kololgi, S.; Salzberg, A. D. \& Koontz, W. W. Jr. The effect of polyethylene glycol-superoxide dismutase administration on histological damage following spermatic cord torsion. J. Urol., 148:639-41, 1992.

Heindel, R. M.; Pakyz, R. E.; Reinking, L. N. \& Cosentino, M. J. The effect of various degrees of unilateral spermatic cord torsion on fertility in the rat. J. Urol., 144:366-9, 1990.

Kehinde, E. O.; Anim, J. T.; Mojiminiyi, O. A.; Al-Awadi, F.; Shihab-Eldeen, A. \& Omu, A. E. Allopurinol provides long-term protection for experimentally induced testicular torsion in a rabbit model. BJU Int., 96:175-80, 2005.
Kotler, M.; Rodríguez, C.; Sáinz, R. M. \& Antolín, I.; Menéndez-Peláez, A. Melatonin increases gene expression for antioxidant enzymes in rat brain cortex. J. Pineal Res., 24:83-9, 1998.

Lysiak, J. J.; Nguyen, Q. A. \& Turner, T. T. Peptide and nonpeptide reactive oxygen scavengers provide partial rescue of the testis after torsion. J. Androl., 23:400-9, 2002.

McAndrew, H. F.; Pemberton, R.; Kikiros, C. S. \& Gollow, I. The incidence and investigation of acute scrotal problems in children. Pediatr. Surg. Int., 18:435-7, 2002.

Nussbaum Blask, A. R.; Bulas, D.; Shalaby-Rana, E.; Rushton, G.; Shao, C. \& Majd, M. Color Doppler sonography and scintigraphy of the testis: a prospective, comparative analysis in children with acute scrotal pain. Pediatr. Emerg. Care., 18:67-71, 2002.

Oner-Iyidogan, Y.; Gürdöl, F. \& Oner, P. The effects of acute melatonin and ethanol treatment on antioxidant enzyme activities in rat testes. Pharmacol. Res., 44:89-93, 2001.

Pablos, M. I.; Chuang, J.; Reiter, R. J.; Ortiz, G. G.; Daniels, W. M.; Sewerynek et al. Time course of the melatonininduced increase in glutathione peroxidase activity in chick tissues. Biol. Signals, 4:325-30, 1995.

Pieri, C.; Marra, M.; Moroni, F.; Recchioni, R. \& Marcheselli, F. Melatonin: A peroxyl radical scavenger more potent than vitamin E. Life. Sci., 55:272-6, 1994.

Prillaman, H. M. \& Turner, T. T. Rescue of testicular function after acute experimental torsion. J. Urol., 157:340-5, 1997.

Power, R. E.; Scanlon, R.; Kay, E. W.; Creagh, T. A. \& Bouchier-Hayes, D.J. Long-term protective effects of hypothermia on reperfusion injury post-testicular torsion. Scand. J. Urol. Nephrol., 37:456-60, 2003.

Reiter, R. J. Functional diversity of the pineal hormone melatonin: Its role as an antioxidant. Exp. Clin. Endocrinol. Diabetes, 104:10-6, 1996.

Reilly, P. M.; Schiller, H. J. \& Bulkley, G. B. Pharmacologic approach to tissue injury mediated by free radical and other reactive oxygen metabolites. Am. J. Surg., 161:488503, 1991. 
Rodriguez, C.; Mayo, J. C.; Sainz, R. M.; Antolín, I., Herrera, F.; Martín, V.; et al. Regulation of antioxidant enzymes: a significant role for melatonin. J. Pineal Res., 36:1-9, 2004.

Romeo, C.; Antonuccio, P.; Esposito, M.; Marini, H.; Impellizzeri, P.; Turiaco, N.; et al. Raxofelast, a hydrophilic vitamin E-like antioxidant, reduces testicular ischemia-reperfusion injury. Urol. Res., 32:367-71, 2004.

Shida, C. S.; Castrucci, A. M. L. \& Lamy-Freund, M. T. High melatonin solubility in aqueous medium. J. Pineal Res., 16:198-201, 1994.

Skoglund, R. W.; McRoberts, J. W. \& Ragde, H. Torsion of the spermatic cord: a review of the literature and an analysis of 70 new cases. J. Urol., 104:604-7, 1970.

Strauss, S.; Faingold, R. \& Manor, H. Torsion of the testicular appendages: sonographic appearance. J. Ultrasound Med., 16:189-92, 1997.

Sun, J.; Liu, G. H.; Zhao, H. T. \& Shi, C. R. Long-term influence of prepubertal testicular torsion on spermatogenesis. Urol. Int., 77:275-8, 2006.

Turner, T. T. \& Brown, K. J. Spermatic cord torsion: Loss of spermatogenesis despite return of blood flow. Biol. Reprod., 49:401-7, 1993.

Turner, T. T.; Bang, H. J. \& Lysiak, J. L. The molecular pathology of experimental testicular torsion suggests adjunct therapy to surgical repair. J. Urol., 172:2574-8, 2004.

Valenti, S. \& Giusti, M. Melatonin participates in the control of testosterone secretion from rat testis: An overview of our experience. Ann. N. Y. Acad. Sci., 966:284-9, 2002.

Visser, A. J. \& Heyns, C. F. Testicular function after torsion of the spermatic cord. BJU Int., 92:200-3, 2003.

Wakatsuki, A.; Okatani, Y.; Izumiya, C. \& Ikenoue, N. Melatonin protects against ischemia and reperfusioninduced oxidative lipid and DNA damage in fetal rat brain. J. Pineal Res., 26:147-52, 1999.

Williamson, R. C. The continuing conundrum of testicular torsion. Br. J. Surg., 72:509-10, 1985.
Correspondence to:

M. Cudi Tuncer

Department of Anatomy

Faculty of Medicine

Dicle University, Diyarbakır

Turkey

Tel: +90 4122488001 Ext. 4539

Fax: +90 4122242083

Email: cudi@dicle.edu.tr

Received: 27-06-2010

Accepted: 02-08-2010 